\title{
Electromagnetic Simulation for the Diagnosis of Lipoprotein Density in Human Blood, a Non-Invasive Approach
}

\author{
Ethan Law ${ }^{1}$, Monika Kakani' ${ }^{2}$, Mangilal Agarwal ${ }^{3,4}$, Maher Rizkalla ${ }^{2,3}$ \\ ${ }^{1}$ Department of Biochemistry, DePauw University, Greencastle, IN, USA \\ ${ }^{2}$ Department of Electrical and Computer Engineering, IUPUI, Indianapolis, IN, USA \\ ${ }^{3}$ Integrated Nanosystem Development Institute, Indianapolis, IN, USA \\ ${ }^{4}$ Department of Mechanical Engineering, IUPUI, Indianapolis, IN, USA \\ Email: mrizkall@iupui.edu
}

How to cite this paper: Law, E., Kakani, M., Agarwal, M. and Rizkalla, M. (2017) Electromagnetic Simulation for the Diagnosis of Lipoprotein Density in Human Blood, a Non-Invasive Approach. Open Journal ot Applied Biosensor, 4, 1-11.

http://doi.org/10.4236/ojab.2017.41001

Received: February 6, 2017

Accepted: February 25, 2017

Published: February 28, 2017

Copyright $\odot 2017$ by authors and Scientific Research Publishing Inc. This work is licensed under the Creative Commons Attribution International License (CC BY 4.0).

http://creativecommons.org/licenses/by/4.0/

\begin{abstract}
With the rise in prevalence of Type II diabetes throughout the world, an increasing need for a portable monitoring system for both blood glucose and lipoprotein concentrations is in demand. Recent work has led to non-invasive wearable devices for monitoring changes in blood glucose concentrations using electromagnetic (EM) waves. However, this still fall short as a means of monitoring cholesterol levels in diabetic patients. The EM study on human tissues emphasized here may also relate to the safety guidelines applied to cellular communications, power lines, and other EM applications. The specific absorption rate (SAR) for the power of the non-ionizing frequency must not exceed a threshold as it impacts DNA and can lead to cancerous tissues. In this study, we used COMSOL software for the investigation of the viability of using EM within the frequency range of $64 \mathrm{MHz}-1 \mathrm{GHz}$ as a means of monitoring the transmission properties of human blood and lipoprotein. In this approach, wave equations were solved within blood and lipoprotein boundaries. Research parameters, including frequency range, Power input (SAR), and lipoprotein densities, were investigated. The transmission properties, produced by the electrical and thermal characteristics of these physiological parameters, have led to proper diagnosis of lipoprotein density. Within the frequency range of $64 \mathrm{MHz}$ to $1 \mathrm{GHz}$, and for a power range of 0.1 to $0.6 \mathrm{SAR}$, lipoprotein density from $1.00 \mathrm{~g} / \mathrm{mL}$ to $1.20 \mathrm{~g} / \mathrm{mL}$ was considered. A 2D model, with an antenna source that supplied the electromagnetic waves to human tissues, was created for the simulations. These were used for the study of the transmission properties of the EM energy into the blood and lipoprotein tissues. While the range of magnetic flux values between simulations varies only slightly or not at all, the distribution of these
\end{abstract}


values is impacted by given parameters. As such, a device capable of comparing magnetic flux values and penetration depths could easily distinguish between samples of different lipoprotein densities. The results obtained in this study can be accommodated non-invasively by human tissues, and can be produced in a practical model using wearable devices. A practical model is proposed for future consideration.

\section{Keywords}

Non-Invasive Monitoring, Cholesterol, Electromagnetic, Biosensors, Wearable Devices

\section{Introduction}

Healthcare applications and wearable devices that allow for mobile monitoring and diagnosis of problematic health factors are a promising new avenue of treatment and diagnosis [1] [2]. Such new developments necessitate the need for devices capable of serving multiple diagnostic purposes. For more than a decade, attention has been given to the usage of electromagnetic waves as a means of non-invasively monitoring physiological characteristics of an individual [3]. Studies of electromagnetic (EM) radiation on human tissues are uniquely suited for medical diagnosis as they offer a wide range of frequencies and magnitudes for potential investigation. Previous studies have yielded promising results of electromagnetic based modalities for cancer research and treatment [4]. Furthermore, EM transmission properties within human tissues may be utilized in the diagnosis of various diseases [3] [4]. The efficacy of applying such forces to patients in vivo has also been evaluated with pleasing results [5].

The EM study for a given operating frequency range on human tissues may also be applied into high technology smart devices within cellular communication systems where the EM frequencies and power could be an issue of human safety [6] [7]. This may lead to proper safety guidelines for smart devices used in communication systems. Likewise, the EM power intensities generated from power lines may have an impact on human health subjects, and therefore, the study presented here may benefit such areas as public health and legal concerns as to the dangers posed by such forces [8] [9] [10]. Since the electromagnetic forces used by wearable devices are applied in a directed manner, there is limited exposure to individuals other than the user. As such, our study only concerns itself with SAR guidelines for the user.

In the Diabetic research area, type II patients, who compose an ever growing cohort, need to constantly monitor their blood glucose levels, often through the usage of "finger prick" glucometers, first invented in 1962 [11] [12]. Through extensive work, viable alternatives to traditional "finger prick" glucometer have been either completed or are nearing completion [11] [12]. In application, these systems use a wristband worn by the individual that provides a means of col- 
lecting impedance data via electromagnetic wave application [11] [12]. In addition to monitoring blood glucose levels, Type II diabetic patients must also be conscious of monitoring and managing their cholesterol levels [13]. Currently, this is done via a blood test, an invasive procedure often requiring the patient to fast prior to the test [14] [15]. The possibility of using the same newly developed non-invasive glucose monitoring devices to monitor separate health characteristics, specifically cholesterol levels, is the subject of this paper. Using the computer modeling software COMSOL, we undertook an investigation into the usage of electromagnetic waves as a means of monitoring cholesterol levels.

The frequency range used in the investigation was chosen so as not to interact with glucose concentration in the blood as a confining variable. Previous work indicated that impedance values for EM studies were noticeable in the range of $33 \mathrm{GHz}$ to $90 \mathrm{GHz}$, far from the range used in this study [16] [17]. Our model is intended to serve as a proof of concept for the efficacy of using EM waves to properly diagnosis the density of lipoprotein tissue on the edge of a blood media. This model mimics the location of lipoprotein in the human body-found on the walls of veins, capillaries, and arties.

\section{Methods}

COMSOL Multiphysics was utilized in the investigation of electromagnetic application on human tissues. A model was created in order to simulate the effect of electromagnetic wave application onto a geometry containing blood and cholesterol of varying densities. Figure 1 shows the 2D simulation model used in the study. The dimensions used here are in the $\mathrm{cm}$ range, making it appropriate for a practical model.

The dimensions of Figure 1 are meant to mimic a human torso comprised solely of blood with a thin layer of lipoprotein lining its outer edge.

The wave equation and the parameters associated with the simulation model are given by:

$$
\nabla \times \mu_{r}^{-1}(\nabla \times \mathbf{E})-k_{0}^{2}\left(\epsilon_{r}-\frac{j \sigma}{\omega \epsilon_{0}}\right) \mathbf{E}=0
$$

where $\sigma$ is the conductivity of the material, $\omega$ is the radian frequency, $\epsilon_{r}$ is the relative permittivity of the blood. The boundary condition at the sample was obtained by matching the tangential components of the electric fields using $n \times \mathrm{E}=0$.

The equations governing the magnetic field study are:

$$
\begin{aligned}
& \nabla \times \mathbf{H}=\mathbf{J} \\
& \mathbf{B}=\nabla \times \mathbf{A} \\
& \mathbf{J}=\sigma \mathbf{E}+j \omega \mathbf{D}+\sigma \mathbf{v} \times \mathbf{B}+\mathbf{J}_{\mathbf{e}} \\
& \mathbf{E}=-j \omega \mathbf{A}
\end{aligned}
$$

The boundary conditions between the blood and lipoprotein materials are given by: 


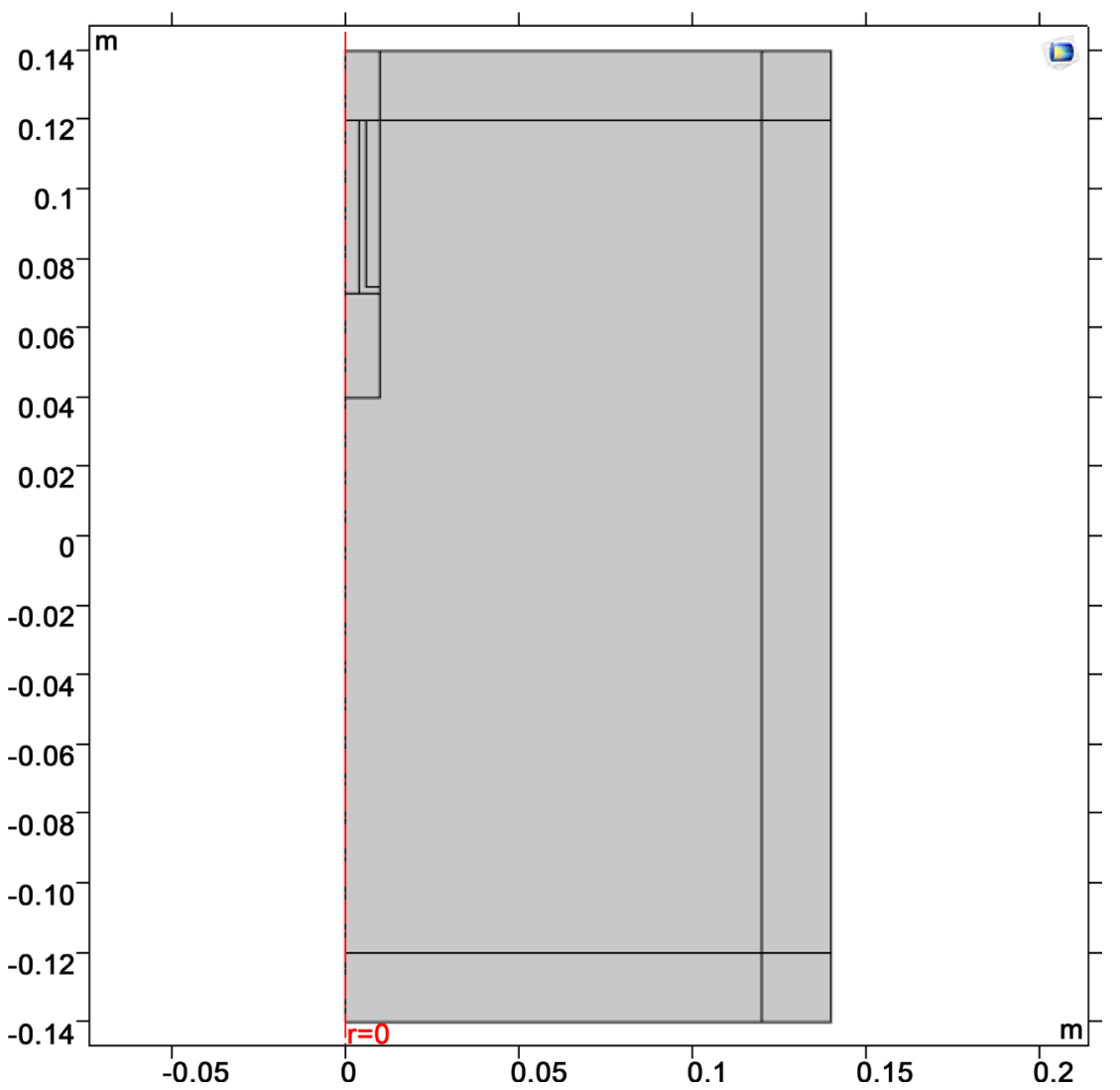

Figure 1. Simulation Model used for our EM Study.

$$
\boldsymbol{n} \times(\nabla \times \boldsymbol{E})-j k \boldsymbol{n} \times(\boldsymbol{E} \times \boldsymbol{n})=0
$$

The wave impedance $\eta$ is given as $\eta=\sqrt{\frac{\mu}{\varepsilon}}$

The power density is estimated from $E^{2} / \eta$

The material properties for the blood and Lipoprotein used in the simulation are given in Table 1 . The global definitions of the research parameters are given in Table 2, and the geometry parameters presented in Table 3.

\section{Results and Discussion}

The three parameters used in the simulation are frequency, SAR values, and lipoprotein density. Frequency values of $64 \mathrm{MHz}, 0.5 \mathrm{GHz}$, and $1 \mathrm{GHz}$ were chosen to investigate a range of possible frequency values. $64 \mathrm{MHz}$ was chosen based on FDA approved frequency for MRI studies. Likewise, the 0.6 SAR was also based on approved values for MRI studies [18]. However, the testing time is short, thus minimizing the energy the tissue is exposed to. The simulation was conducted for three different lipoprotein densities, 1.0, 1.1, 1.2 g/mL. This corresponds to very low density lipoprotein (1.0), a mixture of LDL and HDL (1.1), and very high density lipoprotein (1.2) [19] [20]. The data received from COMSOL simulations addresses the impact of frequency and SAR on the three different density values. Figure 2 represents reference values for a frequency of 
Table 1. Material properties used in the simulation.

\begin{tabular}{|c|c|c|c|c|}
\hline \multicolumn{5}{|c|}{ Material } \\
\hline Property & Blood & Source & Lipoprotein & Frequency $(\mathrm{Hz}) /$ Density $(\mathrm{g} / \mathrm{mL})$ \\
\hline Relative Permeability & 1 & 1 & 1 & \multirow{6}{*}{$64 \mathrm{MHz} / 1.00 \mathrm{~g} / \mathrm{mL}$} \\
\hline Electrical Conductivity & 1.21 & $6.0 \times 10^{7}$ & 2.5 & \\
\hline Relative Permittivity & 86.4 & 1 & 1 & \\
\hline Density & 1050 & - & - & \\
\hline Thermal Conductivity & 0.52 & - & - & \\
\hline Heat Capacity at Constant Pressure & 3617 & - & - & \\
\hline Relative Permeability & 1 & 1 & 1 & \multirow{6}{*}{$0.5 \mathrm{GHz} / 1.10 \mathrm{~g} / \mathrm{mL}$} \\
\hline Electrical Conductivity & 1.38 & $6.0 \times 10^{7}$ & 18.75 & \\
\hline Relative Permittivity & 63.3 & 1 & 1 & \\
\hline Density & 1050 & - & - & \\
\hline Thermal Conductivity & 0.52 & - & - & \\
\hline Heat Capacity at Constant Pressure & 3617 & - & - & \\
\hline Relative Permeability & 1 & 1 & 1 & \multirow{6}{*}{$1 \mathrm{GHz} / 1.20 \mathrm{~g} / \mathrm{mL}$} \\
\hline Electrical Conductivity & 1.58 & $6.0 \times 10^{7}$ & 35 & \\
\hline Relative Permittivity & 61.1 & 1 & 1 & \\
\hline Density & 1050 & - & - & \\
\hline Thermal Conductivity & 0.52 & - & - & \\
\hline Heat Capacity at Constant Pressure & 3617 & - & - & \\
\hline
\end{tabular}

Table 2. Global Parameters Used.

\begin{tabular}{|c|c|c|c|}
\hline Name & Expression & Value & Description \\
\hline $\mathrm{R}_{0}$ & 0.12 & 0.12 & Plasma source radius \\
\hline $\mathrm{Z}_{0}$ & 0.24 & 0.24 & Plasma source height \\
\hline $\begin{array}{l}\text { Psp (change this } \\
\text { to change SAR) }\end{array}$ & $\begin{array}{c}6.51,3.257, \text { or } 1.086[\mathrm{~W}] \\
\text { (Based on SAR Level) }\end{array}$ & $\begin{array}{c}6.51,3.257, \text { or } 1.086[\mathrm{~W}] \\
\text { (Based on SAR Level) }\end{array}$ & $\begin{array}{l}\text { Total power absorbed } \\
\text { by the plasma set point }\end{array}$ \\
\hline Rho_blood & 1050 & 1050 & Blood Density \\
\hline
\end{tabular}

Table 3. Geometry Parameters.

\begin{tabular}{cccccc}
\hline Label & Width & Height & $\mathrm{R}:$ & $\mathrm{Z}$ : & Description \\
\hline Rectangle 1 & $\mathrm{R}_{0}$ & $\mathrm{Z}_{0}$ & 0 & $-\mathrm{z}_{0} / 2$ & Blood \\
Rectangle 2 & 0.01 & 0.03 & 0 & 0.004 & Blood \\
Rectangle 3 & 0.004 & 0048 & 0.006 & 0.072 & Wave Source \\
Rectangle 4 & 0.004 & 0.05 & 0 & 0.07 & Blood \\
Rectangle 5 & $\mathrm{R}_{0}-0.01$ & 0.02 & 0.01 & 0.12 & Blood \\
Rectangle 6 & 0.02 & 0.02 & $\mathrm{R}_{0}$ & 0.12 & Blood \\
Rectangle 7 & 0.04 & $\mathrm{Z}_{0}$ & $\mathrm{R}_{0}-0.02$ & $-\mathrm{z}_{0} / 2$ & Blood \\
Rectangle 8 & 0.02 & 0.02 & $\mathrm{R}_{0}$ & $-0.02-\mathrm{z}_{0} / 2$ & Lipoprotein \\
Rectangle 9 & $\mathrm{R}_{0}$ & 0.02 & 0 & $-0.02-\mathrm{z}_{0} / 2$ & Lipoprotein \\
Rectangle 10 & 0.01 & 0.02 & 0 & 0.12 & Lipoprotein \\
\hline
\end{tabular}




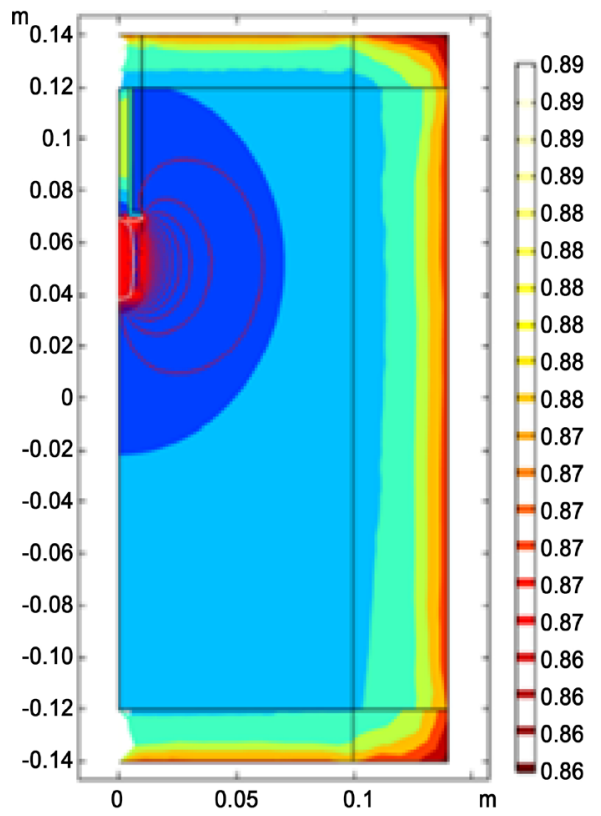

(a)
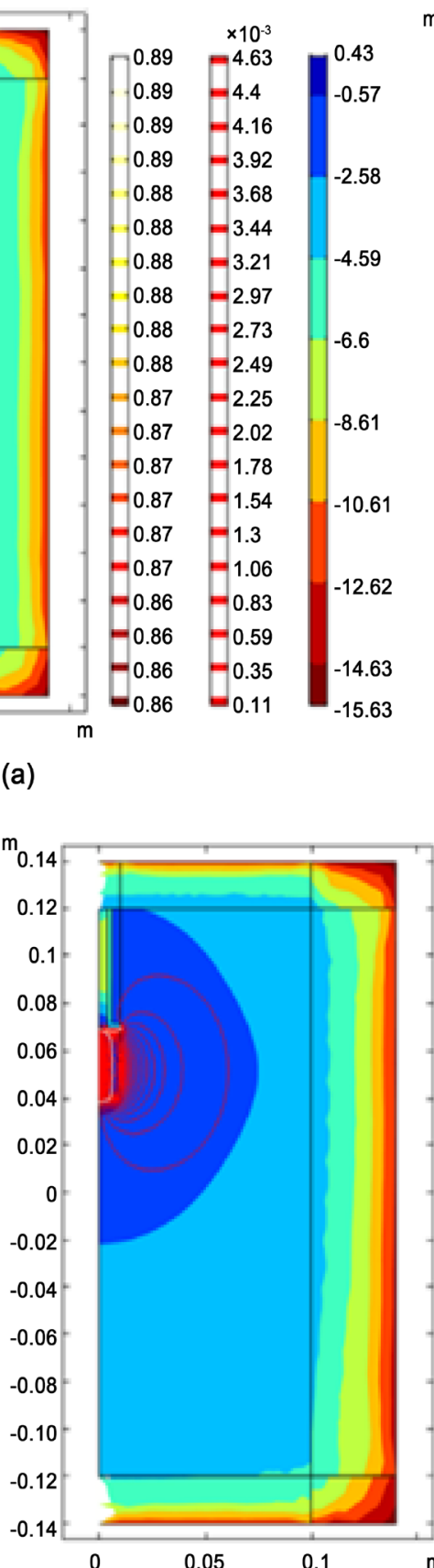

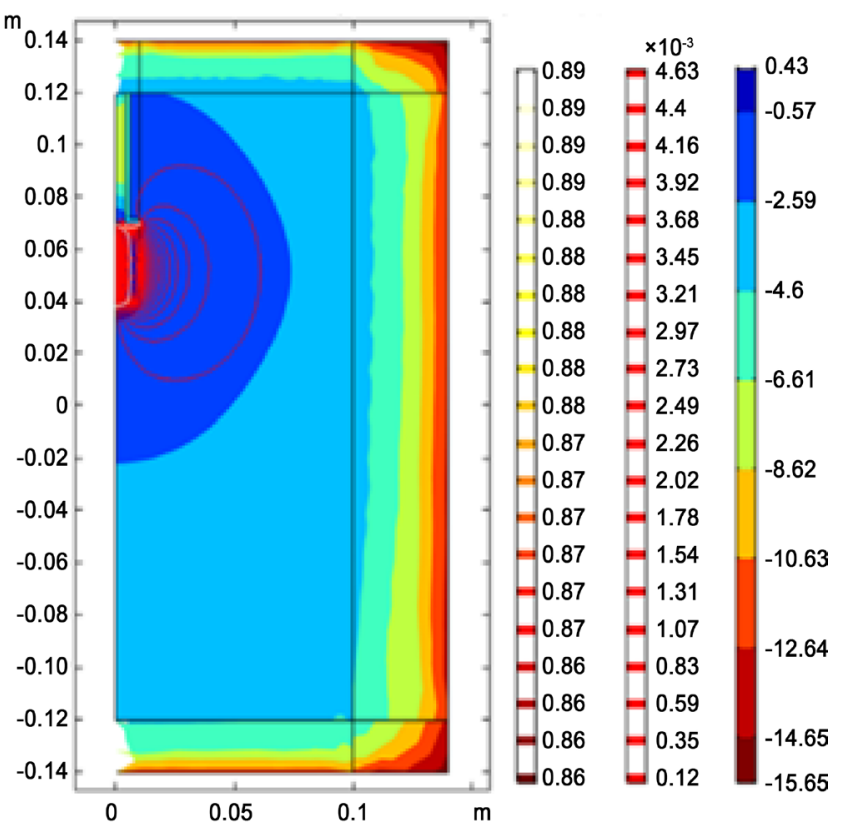

(b)

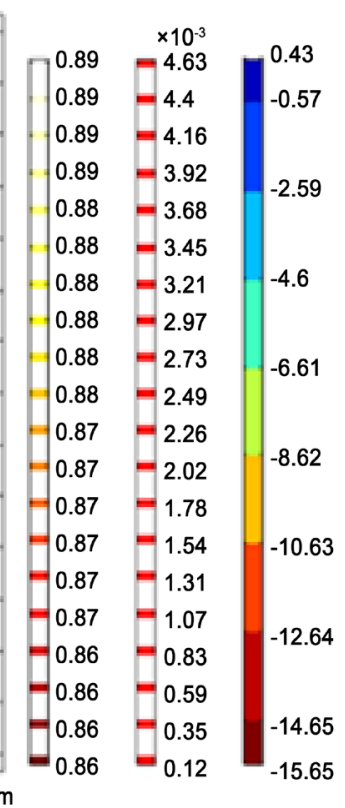

(c)

Figure 2. Magnetic Flux Graphs at $64 \mathrm{MHz}, 0.6$ SAR, and Lipoprotein density ranging from 1.00 (a), $1.1 \mathrm{~g} / \mathrm{mL}$ (b) and $1.20 \mathrm{~g} / \mathrm{mL}$ (c).

$64 \mathrm{MHz}$, SAR of 0.6 , and Lipoprotein density from $1.00 \mathrm{~g} / \mathrm{mL}$ to $1.20 \mathrm{~g} / \mathrm{mL}$ increasing to the right. Figure 3 presents Magnetic Flux values for $1 \mathrm{GHz}, 0.3 \mathrm{SAR}$, and Lipoprotein density from $1.00 \mathrm{~g} / \mathrm{mL}$ to $1.20 \mathrm{~g} / \mathrm{mL}$ increasing to the right. Figure 4 presents Magnetic Flux values for $0.5 \mathrm{GHz}, 0.6 \mathrm{SAR}$, and Lipoprotein density from $1.00 \mathrm{~g} / \mathrm{mL}$ to $1.20 \mathrm{~g} / \mathrm{mL}$ increasing to the right.

Figure 3 and Figure 4 show the magnetic vector potential, $\mathrm{A}$, in $\mathrm{Wb} / \mathrm{m}$ at 0.6 SAR for three different densities $(1,1.1$, and $1.2 \mathrm{~g} / \mathrm{mL})$ and two different fre- 
quencies; $64 \mathrm{MHz}$ and $0.5 \mathrm{GHz}$. The differential A values between the reference $\mathrm{A}(64 \mathrm{MHz})$ and the test $\mathrm{A}(0.5 \mathrm{GHz})$ given at different densities show different penetration depth within the blood material and near the interface with the lipoprotein tissue. The A value near the boundary differ at $1,1.1$, and $1.2 \mathrm{~g} / \mathrm{mL}$ densities for the two frequency values. The change in A at the boundary layers are attributed to the impact of the density values. This differential potential can be tracked or monitored via magnetic sensor devices and the lipoprotein density may be estimated. The differential magnetic potentials are tabulated in Table 4 .

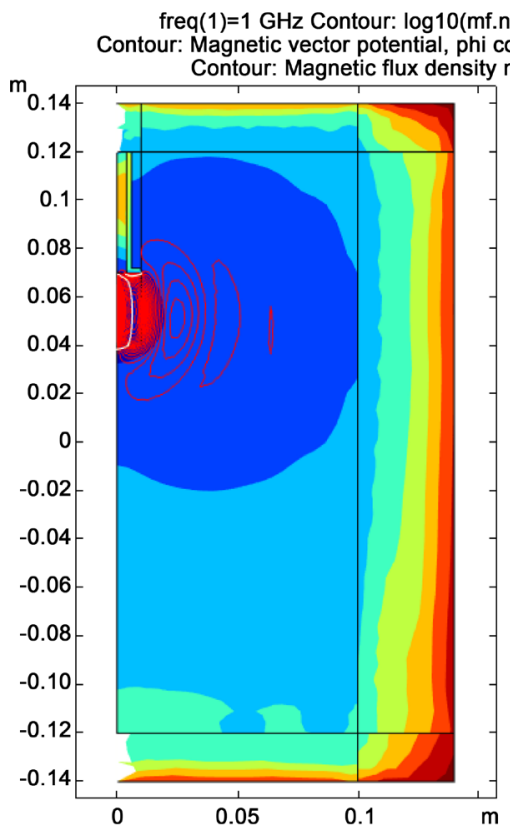

(a)

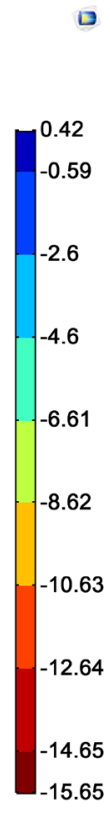

(1)

(b)

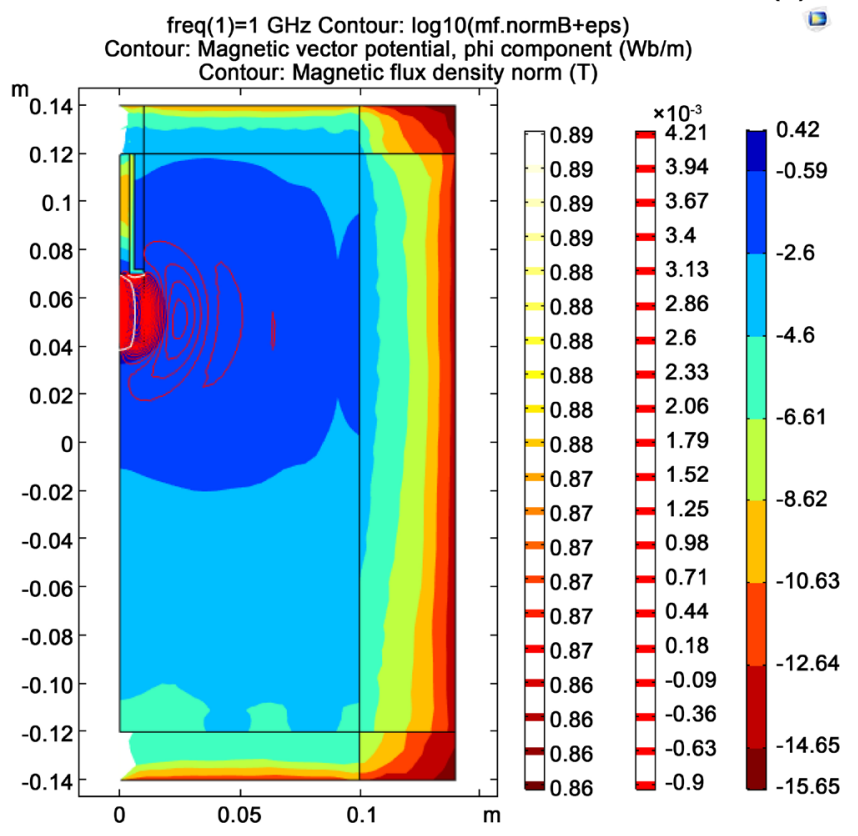

(c)

Figure 3. Magnetic Flux Graphs at $1 \mathrm{GHz}, 0.3 \mathrm{SAR}$, and Lipoprotein density ranging from 1.00 (a), $1.1 \mathrm{~g} / \mathrm{mL}$ (b) to $1.20 \mathrm{~g} / \mathrm{mL}$ (c). 


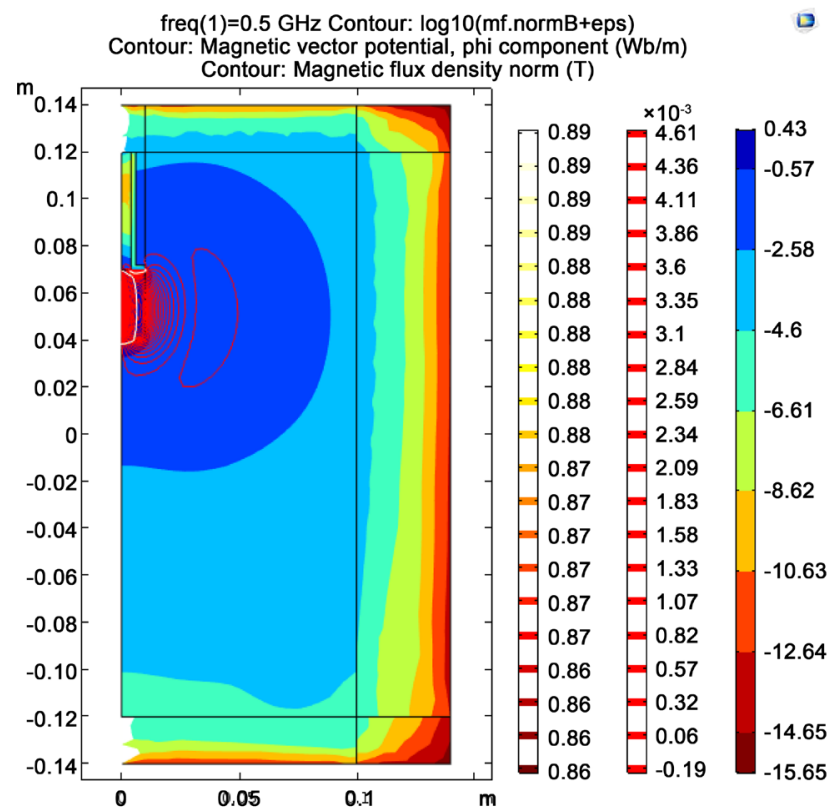

(a)

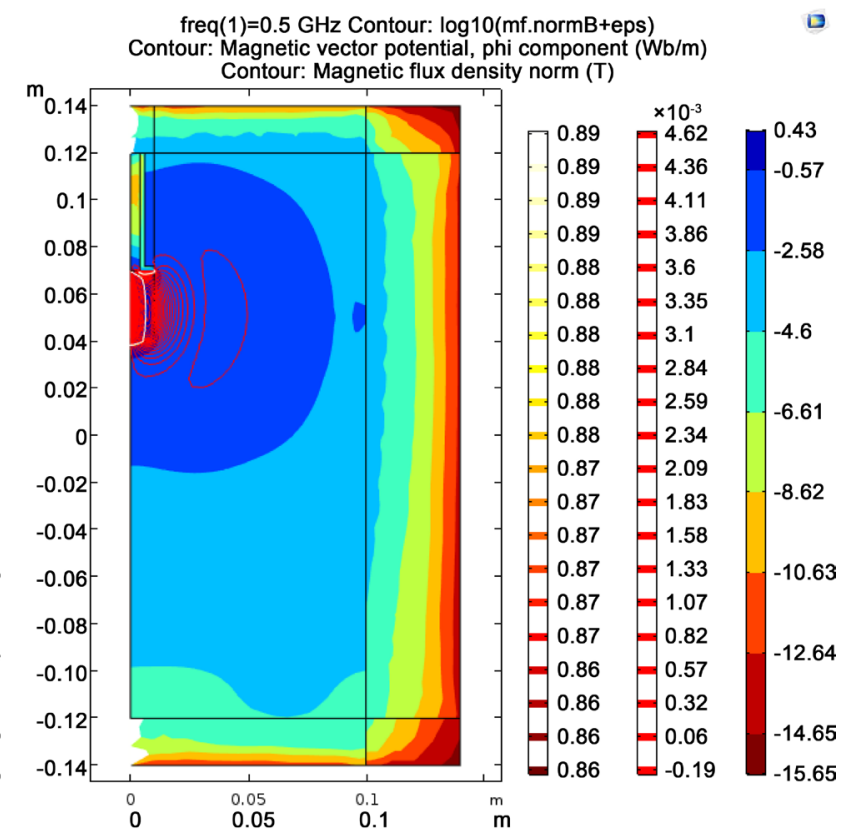

(b)

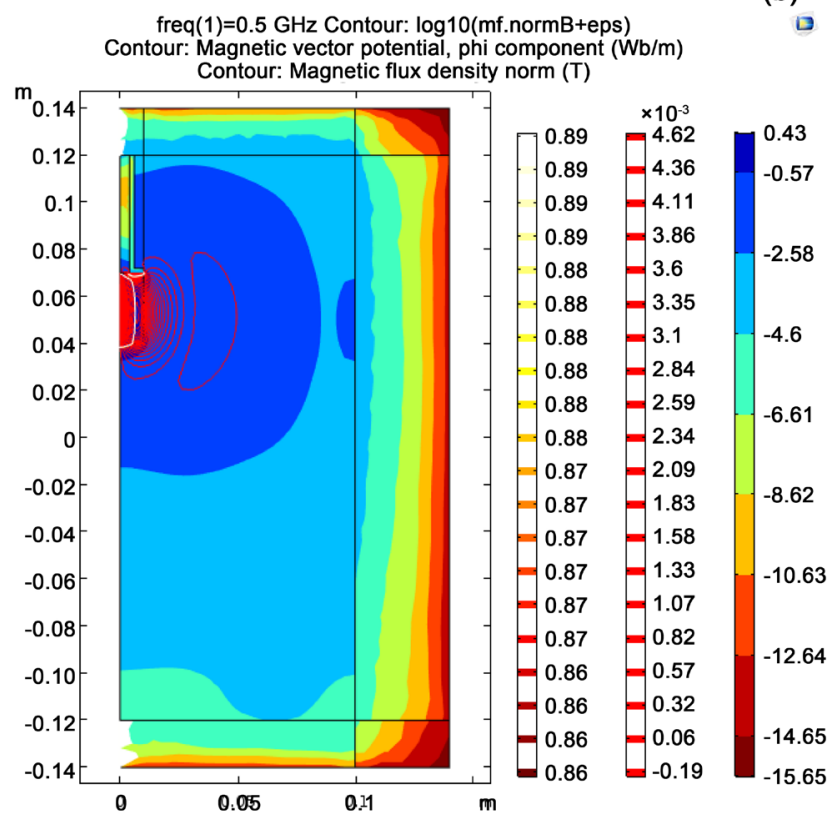

(c)

Figure 4. Magnetic Potentials at $0.5 \mathrm{GHz}, 0.6 \mathrm{SAR}$, and Lipoprotein density ranging from 1.00 (a) $1.1 \mathrm{~g} / \mathrm{mL}$ (b) to $1.20 \mathrm{~g} / \mathrm{mL}$ (c).

Table 4. Penetration of EM magnetic potentials for $64 \mathrm{MHz}$ and $0.5 \mathrm{GHz}$ at $0.6 \mathrm{SAR}$.

\begin{tabular}{ccccccc}
\hline \multicolumn{3}{c}{$64 \mathrm{MHz}$} & & \multicolumn{2}{c}{$0.5 \mathrm{GHz}$} \\
\hline $\begin{array}{c}\text { Lipoprotein } \\
\text { Density }\end{array}$ & $\begin{array}{c}\text { Penetration of } \\
(>-2.58) \mathrm{Wb} / \mathrm{m} \\
\text { values into Blood }\end{array}$ & $\begin{array}{c}\text { Penetration of }(-2.58 \text { to } \\
-4.6) \mathrm{Wb} / \mathrm{m} \text { values into } \\
\text { Lipoprotein }\end{array}$ & $\begin{array}{c}\text { Presence of } \\
(>-2.58) \mathrm{Wb} / \mathrm{m} \\
\text { values at Boundary }\end{array}$ & $\begin{array}{c}\text { Penetration of } \\
(>-2.58) \mathrm{Wb} / \mathrm{m} \\
\text { values into Blood }\end{array}$ & $\begin{array}{c}\text { Penetration of }(-2.58 \text { to } \\
-4.6) \mathrm{Wb} / \mathrm{m} \text { values into } \\
\text { Lipoprotein }\end{array}$ & $\begin{array}{c}\text { Presence of } \\
(>-2.58) \mathrm{Wb} / \mathrm{m} \\
\text { values at Boundary }\end{array}$ \\
\hline $1.00 \mathrm{~g} / \mathrm{mL}$ & $7 \mathrm{~cm}$ & $1.5 \mathrm{~cm}$ & No & $8.5 \mathrm{~cm}$ & $0.5 \mathrm{~cm}$ & No \\
$1.10 \mathrm{~g} / \mathrm{mL}$ & $7.5 \mathrm{~cm}$ & $1 \mathrm{~cm}$ & No & $8 \mathrm{~cm}$ & $0.5 \mathrm{~cm}$ & $0.5 \mathrm{~cm}$ \\
$1.20 \mathrm{~g} / \mathrm{mL}$ & $7.5 \mathrm{~cm}$ & $1 \mathrm{~cm}$ & No & $7.5 \mathrm{~cm}$ & $0.5 \mathrm{~cm}$ & $1 \mathrm{~cm}$ \\
\hline
\end{tabular}




\section{Conclusions and Future Work}

Using range values for magnetic flux generated via simulation, we observed no useful differential values for the diagnosis of lipoprotein density. However, the distribution of these magnetic flux values across these ranges varied greatly when parameters were changed, as presented visually in Figures 2-4. The total summation of magnetic flux over a defined area will therefore also vary when parameters are changed and could be used to properly diagnose the density of lipoprotein tissue. The simulation given at $64 \mathrm{MHz}$ was considered the reference value for the estimation of the differential potentials at different frequencies for various densities. $64 \mathrm{MHz}$ was chosen as it is commonly used in medical applications such as MRI studies and has been FDA approved [18].

We envision a wearable wristband system similar to that of previous studies into non-invasive glucose monitoring [11] [12]. Our current models suggest the usage of RF sources for both $64 \mathrm{MHz}$ and $0.5 \mathrm{GHz}$ at corresponding locations on the skin tissue. Possible materials for these wristbands include highly flexible bismuth Hall sensors on polymeric foils [16]. These sensors were designed with such applications in mind and could be adapted to fit either the inserted catheter or external source models we envision for future studies. Magnetic sensors with analog devices may be utilized for monitoring the change in magnetic vector potentials at 8 locations shown in Figure 5 for the $12 \mathrm{~cm}$ size layers, covering both the blood and lipoprotein tissue.

The current model does not incorporate skin moisture, skin tissue, muscle tissue, and bone. As such, a comprehensive model will be needed that takes into account the transmission properties of these parameters. The addition of these parameters may cause an EM power attenuation. In such a case, a higher transmitted EM power may be considered in order to reach 0.6 SAR within the blood.

Following the data presented in Table 4, a comparison of the magnetic field at different locations for both $64 \mathrm{MHz}$ and $0.5 \mathrm{GHz}$ is necessary. This may be accomplished by implementing complementary magnetic sensors arranged in matrices on flexible substrates at suitable locations. Four (4) by two (2) sensor metrics, as shown in Figure 5, allowing for comparison of sensor information in

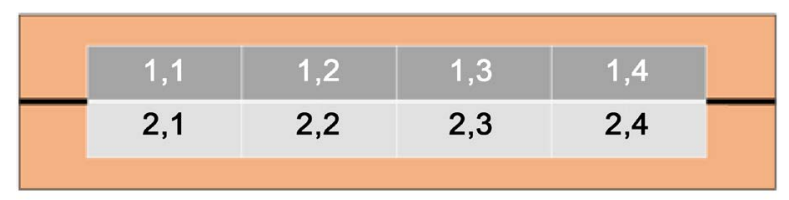

Matrix of $64 \mathrm{MHz}$ Sensors

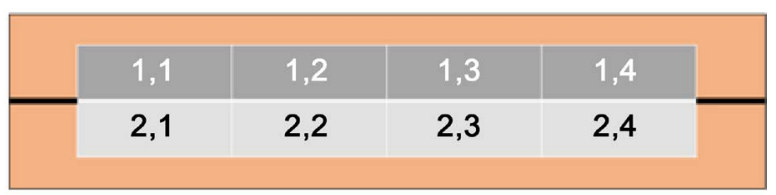

Matrix of $0.5 \mathrm{GHz}$ Sensors

Figure 5. Proposed Practical Model for the Lipoprotein Density Monitoring System. 


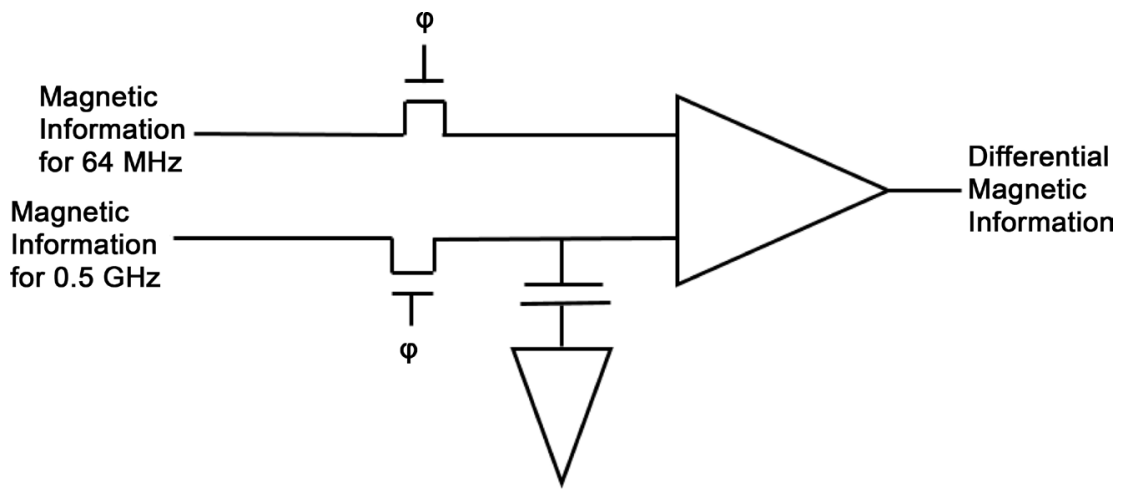

Figure 6. Proposed Sample and Hold off Circuit Model.

location 1,1 for instance at $64 \mathrm{MHz}$ with location 1,1 at $0.5 \mathrm{GHz}$ are suited to this task. A differential sample and hold off circuit, as shown in Figure 6, may be utilized to provide a comparator that compares the two magnetic field patterns at both frequencies in corresponding locations. In this figure, a MOSFET switching device will enable the passing of the sensor information into the comparator circuit. The magnetic sensing information from the $64 \mathrm{MHz}$ is used as a reference potential. Figure 5 and Figure 6 give a proposed idea for the practical model of the system. The details of the system hardware and its implementation are reserved for future considerations.

\section{Acknowledgements}

The authors would like to offer their great appreciation to the National Science Foundation for their support through the Research Experience for Undergraduate Students (REU) program (Award \# 1659688). The authors would like to thank the INDI faculty and staff at IUPUI for their support and guidance throughout the work of this research.

\section{References}

[1] Wu, I.-L., Li, J.-Y. and Fu, C.-Y. (2011) The Adoption of Mobile Healthcare by Hospitals Professionals: An Integrative Perspective. Decision Support Systems, 51, 587-596. https://doi.org/10.1016/j.dss.2011.03.003

[2] Rodgers, M.M., Pai, V.M. and Conroy, R.S. (2015) Recent Advances in Wearable Sensors for Health Monitoring. IEEE Sensors Journal, 15, 3119-3126. https://doi.org/10.1109/JSEN.2014.2357257

[3] Woodward, R.M., Wallace, V.P., Pye, R.J., Cole, B.E., Arnone, D.D., Linfield, E. and Pepper, M. (2003) Terahertz Pulsed Imaging for EX Vivo Basal Cell Carcinoma. Journal of Investigative Dermatology, 120, 72-78. https://doi.org/10.1046/j.1523-1747.2003.12013.x

[4] Gildea, T.R., et al. (2006) Electromagnetic Navigation Diagnostic Bronchoscopy: A Prospective Study. American Journal of Respiratory and Critical Care Medicine, 174, 982-989. https://doi.org/10.1164/rccm.200603-344OC

[5] Jensen, K.W., et al. (2012) Multicenter Experience with Electromagnetic Navigation Bronchoscopy for the Diagnosis of Pulmonary Nodules. Journal of Bronchology \& Interventional Pulmonology, 19, 195-199. 
https://doi.org/10.1097/LBR.0b013e3182616ece

[6] Pickwell, E., Cole, B.E., Fitzgerald, A.J., Pepper, M. and Wallace, V.P. (2004) In Vivo Study of Human Skin Using Pulsed Terahertz Radiation. Physics in Medicine and Biology, 49, 1595-1607. https://doi.org/10.1088/0031-9155/49/9/001

[7] Agarwal, A., et al. (2008) Effect of Cell Phone Usage on Semen Analysis in Men Attending Infertility Clinic: An Observational Study. Fertility and Sterility, 89, 124-128. https://doi.org/10.1016/j.fertnstert.2007.01.166

[8] Hardell, L. and Sage, C. (2008) Biological Effects from Electromagnetic Field Exposure and Public Exposure Standards. Biomedicine \& Pharmacotherapy, 62, 104-109. https://doi.org/10.1016/j.biopha.2007.12.004

[9] Panagopoulos, D.J., Karabarbounis, A. and Margaritis, L.H. (2002) Mechanism for Action of Electromagnetic Fields on Cells. Biochemical and Biophysical Research Communications, 298, 95-102.

[10] Bennett, W.R. (1994) Cancer and Power Lines. Physics Today, 47, 23-31. https://doi.org/10.1063/1.881417

[11] Yoo, E.-H. and Lee, S.-Y. (2010) Glucose Biosensors: An Overview of Use in Clinical Practice. Sensors, 10, 4558-4576.

[12] Chung, J., Choi, H.S. and Wong, T.K.S. (2012) Recent Advances in Noninvasive Glucose Monitoring. Medical Devices. Evidence and Research, 5, 45-52.

[13] Malinin, L. (2012) Development of a Non-Invasive Blood Glucose Monitor Based on Impedance Measurements. International Journal of Biomedical Engineering and Technology, 8, 60 .

[14] Solano, M.P. and Goldberg, R.B. (2006) Lipid Management in Type 2 Diabetes. Clinical Diabetes, 24, 27-32. https://doi.org/10.2337/diaclin.24.1.27

[15] Grover, S.A., Coupal, L. and Hu, X. (1995) Identifying Adults at Increased Risk of Coronary Disease How Well Do the Current Cholesterol Guidelines Work? JAMA, 274, 801-806. https://doi.org/10.1001/jama.1995.03530100041032

[16] Melzer, M., Mönch, J.I., Makarov, D., Zabila, Y., Cañón Bermúdez, G.S., Karnaushenko, D., Baunack, S., Bahr, F., Yan, C., Kaltenbrunner, M. and Schmidt, O.G. (2015) Wearable Magnetic Field Sensors for Flexible Electronics. Advanced Materials, 27, 1274-1280.

[17] Sasha, S., Cano-Garcia, H., Sotiriou, I., Lipscombe, O., Gouzouasis, I., Koutsoupidou, M., Palikaras, G., Mackenzie, R., Reeve, T., Kosmas, P. and Efthymios (2017) A Glucose Sensing System Based on Transmission Measurements at Millimeter Waves using Micro strip Patch Antennas. Scientific Reports, 7.

[18] Collins, C.M., et al. (2004) Temperature and SAR Calculations for a Human Head within Volume and Surface Coils at 64 and $300 \mathrm{MHz}$. Journal of Magnetic Resonance Imaging, 19, 650-656. https://doi.org/10.1002/jmri.20041

[19] Gooch, J.W. (2011) Very Low Density Lipoprotein (VLDL). Encyclopedic Dictionary of Polymers, 931. https://doi.org/10.1007/978-1-4419-6247-8_15082

[20] Wang, H., Han, C., Wang, H., Jin, Q., Wang, D., Cao, L. and Wang, G. (2011) Simultaneous Determination of High-Density Lipoprotein, Very Low-Density Lipoprotein and Low-Density Lipoprotein Subclass in Human Serum by Microchip CE. Chromatographia, 74, 799-805. 
Submit or recommend next manuscript to SCIRP and we will provide best service for you:

Accepting pre-submission inquiries through Email, Facebook, LinkedIn, Twitter, etc. A wide selection of journals (inclusive of 9 subjects, more than 200 journals)

Providing 24-hour high-quality service

User-friendly online submission system

Fair and swift peer-review system

Efficient typesetting and proofreading procedure

Display of the result of downloads and visits, as well as the number of cited articles Maximum dissemination of your research work

Submit your manuscript at: http://papersubmission.scirp.org/

Or contact ojab@scirp.org 